\title{
Phanerozoic environments of black shale deposition and the Wilson Cycle
}

\author{
J. Trabucho-Alexandre ${ }^{1,2}$, W. W. Hay ${ }^{3}$, and P. L. de Boer ${ }^{1}$ \\ ${ }^{1}$ Sedimentology Group, Department of Earth Sciences, Utrecht University, Budapestlaan 43584 CD Utrecht, The Netherlands \\ ${ }^{2}$ Durham University, Department of Earth Sciences, South Road, Durham, DH1 3LE, UK \\ ${ }^{3} 2045$ Windcliff Dr., Estes Park, Colorado 80517, USA \\ Correspondence to: J. Trabucho-Alexandre (joao.trabucho@durham.ac.uk)
}

Received: 4 September 2011 - Published in Solid Earth Discuss.: 8 September 2011

Revised: 16 January 2012 - Accepted: 24 January 2012 - Published: 2 February 2012

\begin{abstract}
The spatial and temporal distribution of black shales is related to the development of environments in which they accumulate and to a propitious combination of environmental variables. In recent years, much has been done to improve our understanding of the mechanisms behind the temporal distribution of black shales in the Phanerozoic and of the environmental variables that result in their deposition. However, the interpretation of ancient black shale depositional environments is dominated by an oversimplistic set of three depositional models that do not capture their complexity and dynamics. These three models, the restricted circulation, the (open) ocean oxygen minimum and the continental shelf models, are an oversimplification of the variety of black shale depositional environments that arise and coexist throughout the course of a basin's Wilson Cycle, i.e. the dynamic sequence of events and stages that characterise the evolution of an ocean basin, from the opening continental rift to the closing orogeny. We examine the spatial distribution of black shales in the context of the Wilson Cycle using examples from the Phanerozoic. It is shown that the geographical distribution of environments of black shale deposition and the position of black shales in the basin infill sequence strongly depend on basin evolution, which controls the development of sedimentary environments where black shales may be deposited. The nature of the black shales that are deposited, i.e. lithology and type of organic matter, also depends on basin evolution and palaeogeography. We propose that in studies of black shales more attention should be given to the sedimentary processes that have led to their formation and to the interpretation of their sedimentary environments.
\end{abstract}

\section{Introduction}

Even though fine-grained sedimentary rocks are the most ubiquitous component of the stratigraphic record (Potter et al., 1980), the distribution of black shales in the Phanerozoic is predominantly limited to six stratigraphic intervals (Fig. 1), which together represent about one-third of Phanerozoic time (Klemme and Ulmishek, 1991). The petroleum source rocks in these intervals have provided more than $90 \%$ of the world's known reserves of hydrocarbons (Tissot, 1979; Klemme and Ulmishek, 1991). The temporal and spatial distribution of black shales, a key factor controlling the occurrence of petroleum (White, 1993; Otis and Schneidermann, 1997), is related to the development in time and space of environments in which black shales may accumulate and to a propitious combination of environmental variables: organic productivity, subsequent preservation of organic matter and appropriate sedimentation rates (Katz, 2005; Tyson, 2005). The preservation of organic matter is, in turn, dependent on several (partly) independent and interacting variables such as organic matter type, sea water oxygenation, sediment grain size, burial rates and natural vulcanisation processes (Stow et al., 2001).

"Black shale" is commonly used in the geological literature as a moniker for a variety of fine-grained organic matter-rich lithologies (Fig. 2) deposited in a broad swathe of sedimentary environments from lakes to the abyssal plains of the ocean (Arthur, 1979; Jenkyns, 1980; Waples, 1983; Bohacs et al., 2000; Tyson, 2005). Depending on sedimentary environment, black shales can be deposited by any one or combination of processes that control fine-grained sedimentation: pelagic settling, hemipelagic deposition (including lateral advection of sediment), hemiturbiditic and 


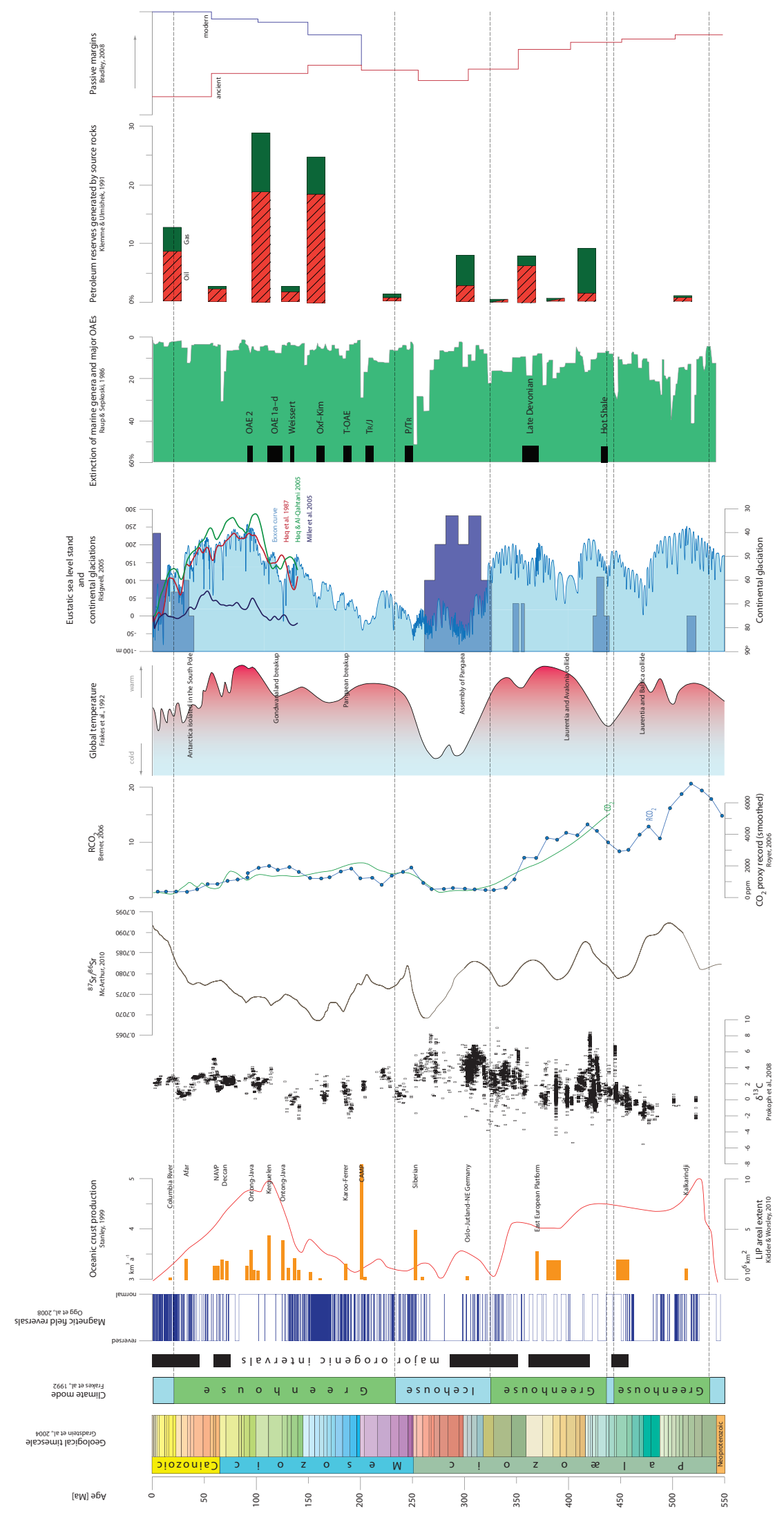

Fig. 1. Caption on next page. 
Fig. 1. Phanerozoic patterns of various indicators of global change. From left to right: Phanerozoic geological timescale (Gradstein et al., 2004), climate mode (Frakes et al., 1992), major orogenic intervals, magnetic field reversals (Ogg et al., 2008), oceanic crust production (Stanley, 1999) and LIP aereal extent (Kidder and Worsley, 2010), carbon isotope curve (Prokoph et al., 2008), strontium isotope curve (McArthur, 2010), $\mathrm{RCO}_{2}$ and $\mathrm{CO}_{2}$ proxy record (Berner, 2006; Royer, 2006), global temperature (Frakes et al., 1992), eustatic sea level stand (Exxon curve; Haq et al., 1987; Haq and Al-Qahtani, 2005; Miller et al., 2005), continental glaciations (Ridgwell, 2005), extinction of marine genera and major oceanic anoxic events (OAEs) (Raup and Sepkoski, 1986), petroleum reserves generated by source rocks (Klemme and Ulmishek, 1991), and passive margin extension (Bradley, 2008).

contouritic sedimentation, turbidity currents, hyperpycnal and debris flows, slides and slumps (Stow et al., 2001). It has been amply demonstrated in the literature that black shales are much more varied than often assumed, and that casual inspection of hand samples is in most cases insufficient to determine the physical processes that led to their formation (Rine and Ginsburg, 1985; Macquaker et al., 2007, 2010; Schieber and Southard, 2009; Schieber, 2011; TrabuchoAlexandre et al., 2011, 2012). The term "black shale" therefore groups rocks with very different origins and characteristics (Fig. 2), but which have in common an organic matter content that is higher than the average marine rock (cf. Creaney and Passey, 1993). Consequently, in order to effectively understand, compare and correlate coeval black shales deposited in different (parts of) basins, it is important to determine which sedimentary processes led to their deposition and, particularly, in which depositional environment they formed.

The interpretation of ancient environments in which black shales were deposited has been strongly influenced by observations in modern environments where organic matter presently accumulates. Therefore, uniformitarian depositional models are commonly applied in their interpretation (see Arthur and Sageman, 1994). Traditionally, three models are used to summarise the range of environments in which black shales can accumulate: the restricted circulation, the open ocean (oxygen minimum), and the continental shelf models (Didyk et al., 1978; Tourtelot, 1979). A common theme in these models is a geographical and oceanographical situation that renders seawater in these environments oxygen-poor (Arthur and Sageman, 1994; their Fig. 1). These depositional models, it will be argued, do not encompass all black shale depositional environments created during the course of a basin's Wilson Cycle, i.e. the plate tectonic process of ocean formation and closure (Dewey and Burke, 1974). The coeval occurrence of sedimentologically unrelated lithologies deposited in disparate sedimentary environments is potentially one of the reasons why conflicting interpretations of data, due to different estimates of the extent of "black shale" deposition and of ocean anoxia, continue to generate much discussion in the literature (e.g. Ryan and Cita, 1997; van Andel et al., 1977; Demaison and Moore, 1980; Waples, 1983; Degens et al., 1986; Pedersen and Calvert, 1990; Piper and Calvert, 2009).

We apply J. Tuzo Wilson's remarkable idea that ocean basins have a life cycle and that "each stage has its own characteristic rock types and structures" (Wilson, 1968) to Phanerozoic black shales. Black shales may be deposited during most stages of the Wilson Cycle, but the depositional environment and partly also the type of black shale (Fig. 2) depend, for each basin, on the Wilson Cycle stage. Similarly, black shales were deposited throughout the Phanerozoic, but periods of relatively widespread black shale deposition coincided with periods of increased volcanic and tectonic activity (Fig. 1). Whilst each basin has its own tectonic history that may be more or less complex, the evolution of their depositional environments is mostly similar (Fig. 3). Examples from different time intervals in the Phanerozoic (Klemme and Ulmishek, 1991) illustrate how basin development controls the distribution of environments of black shale deposition in time and space and, partly, the characteristics of black shales deposited in those environments (Table 1). The resulting models represent a comprehensive and dynamic view of ancient environments of black shale accumulation; therefore, they are more useful in the interpretation of black shales than the existing three models in isolation.

\section{Plate tectonics and exogenic processes}

Prior to the 1960s plate tectonics revolution, the Earth was largely regarded as a "rigid, stable body whose surface features have evolved slowly by processes [one could] see in action [at present]" (Wilson, 1968). Nowadays, it is amply acknowledged that the transition from intracontinental rift to ocean basin (Fig. 3a-f) occurred repeatedly since at least the Late Archaean (Kearey et al., 2009). The former existence of ancient oceans is implied by continent reconstructions and by fragments of ancient oceanic crust preserved in orogenic belts.

The internal heat of the Earth drives tectonic processes which, in turn, (1) lead to changes in the geography of the Earth (e.g. Scotese, 2004) and (2) affect climate over both extremely rapid (e.g. Storey et al., 2007) and long timescales (e.g. Raymo and Ruddiman, 1992). Changes in the geography of the Earth exert an important control on both climate and oceanography which affect the behaviour of sedimentary systems, productivity in the ocean and the oxygen content of seawater. The distribution of continents and ocean basins, their latitudinal position, basin connectivity via the opening and closure of gateways, amongst other palaeogeographical changes, are important controls on regional and global climate and oceanography. The mechanisms by which climate 


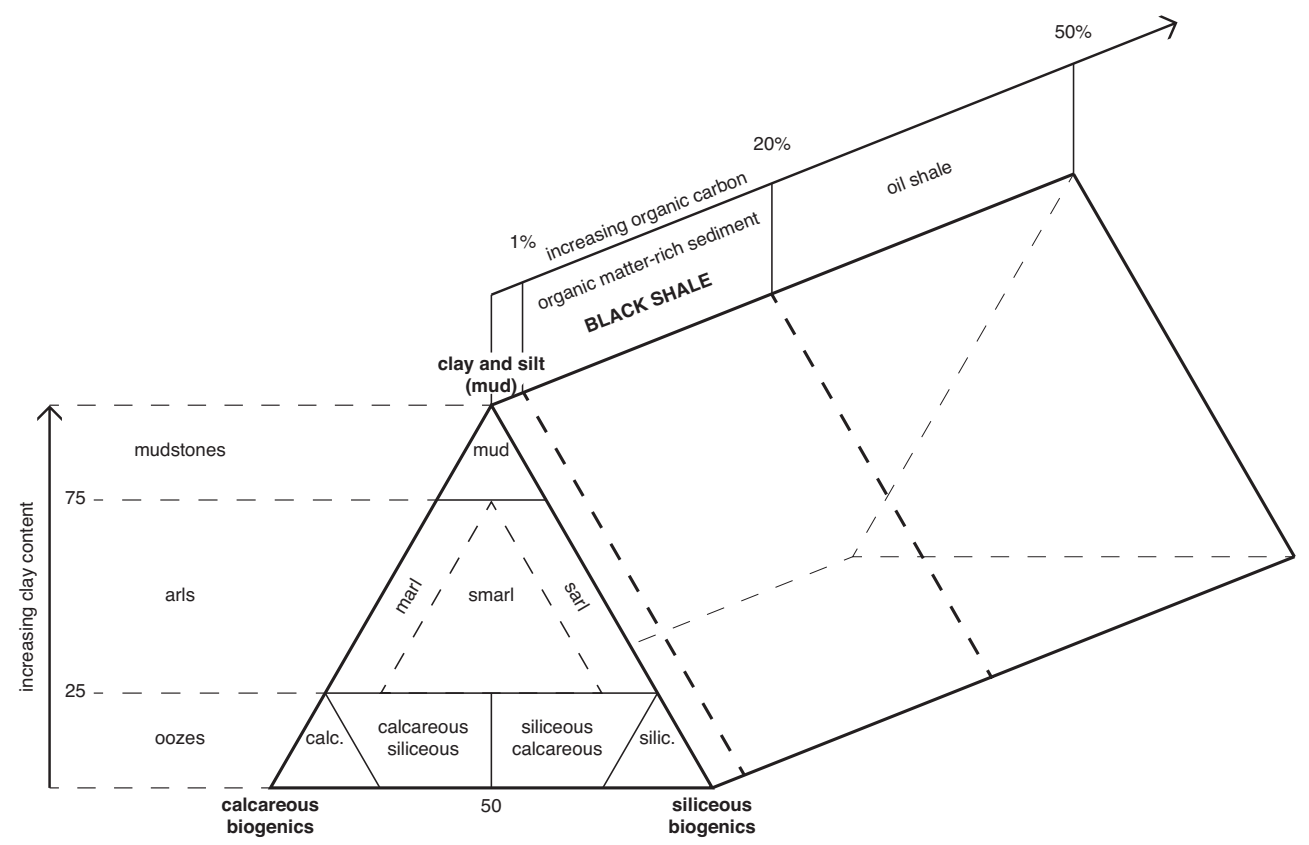

Fig. 2. Classification of fine-grained marine rocks based on composition. Black shales are organic matter-rich sedimentary rocks with varying relative proportions of mud and biogenic components.

Table 1. Summary of black shale occurrence with respect to Wilson Cycle stages and their respective depositional environments.

\begin{tabular}{|c|c|c|c|c|c|}
\hline Wilson stage & & Example & Processes & Environments & Black shales \\
\hline \multirow[t]{2}{*}{ Continental rift } & Terrestrial & East African rift & Crustal thinning, uplift & Alluvial, lakes & Lacustrine \\
\hline & Flooded & Aegean Sea & As above, seawater intrusion & Restricted shallow marine, fan deltas & Shallow marine \\
\hline Juvenile basin & & Red Sea & Spreading, uplift & Small shelves, shallow seafloor & If estuarine \\
\hline \multirow[t]{2}{*}{ Mature ocean } & Opening & Atlantic Ocean & Spreading & Extensive shelves, deep seafloor & Shelf \\
\hline & Closing & Pacific Ocean & Spreading, subduction & Narrow shelves, very deep seafloor & Upwelling zones \\
\hline Volcanic arc & & Western Pacific Ocean & Subduction, volcanism & Backarc basin, abyssal seafloor & No \\
\hline Terminal & & Mediterranean Sea & Compression, uplift & Marginal basin & If estuarine \\
\hline \multirow[t]{2}{*}{ Foreland basin } & Peripheral & Persian Gulf & Lithospheric flexure, subsidence & Marginal basin & Fluvio-deltaic, shallow marine \\
\hline & Retroarc & Andean Basins & & Marginal basin & Fluvio-deltaic, shallow marine \\
\hline Orogen & & Himalaya & Compression, uplift & Alluvial & No \\
\hline
\end{tabular}

change occurs are complex. For instance, whilst the absence of continents in polar position precludes glaciations, their presence near the poles does not imply a glaciation. Seafloor spreading and mountain building, both driven by tectonic processes, control Earth's climate over long timescales because they lead to changes in $\mathrm{CO}_{2}$ input by volcanism and dissociation of subducted limestones, and its removal by weathering of silicates and organic matter burial (Berner, 1991). Volcanism related to plate tectonic processes can also drive rapid climate change both directly due to faster seafloor spreading rates (Berner et al., 1983), increasing length of oceanic ridges and by the extrusion of large igneous provinces (e.g. Sinton and Duncan, 1997; Kerr, 1998), and indirectly due to greenhouse gas generation as a consequence of increased seawater temperatures (e.g. Dickens et al., 1995; Hesselbo et al., 2000) and contact metamorphism (e.g. McElwain et al., 2005; Storey et al., 2007).

Plate tectonics further results in the continual creation and destruction of sediment sources, transport paths and sinks at the surface of the Earth. Sea level, which depends both on global and local tectonics and on climate, controls the size and distribution of shallow marine and paralic environments, where the vast majority of ancient black shales were deposited (e.g. Walsh, 1991; Wignall, 1991; Hedges and Keil, 1995; Laws et al., 2000; Arthur and Sageman, 2004). Climate, forced by tectonic processes and by subtle cyclic variations in the Earth's axis and orbit (de Boer and Smith, 1994), also plays a fundamental role in the evolution of sedimentary environments on Earth. Nevertheless, in the Phanerozoic, the geographical distribution of black 


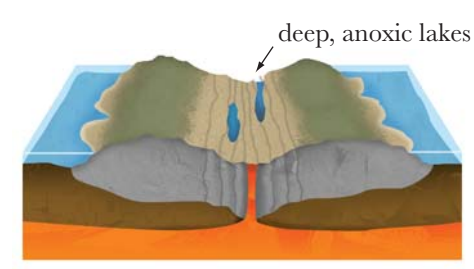

A: Continental rift

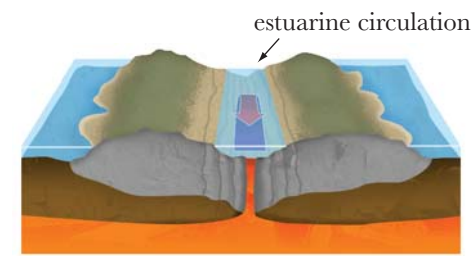

B: Flooded continental rift

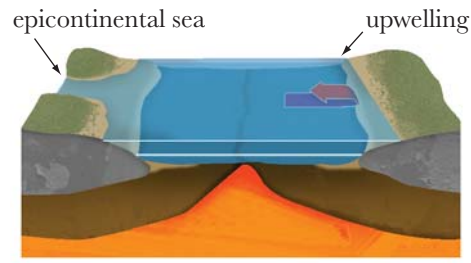

C: Expanding ocean basin

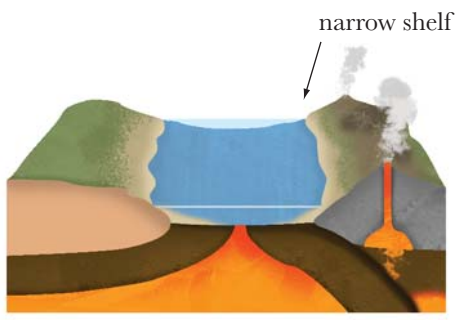

D: Mature ocean basin

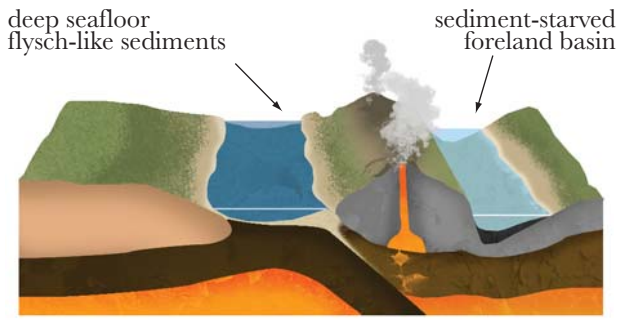

E: Closing ocean basin

and foreland basin

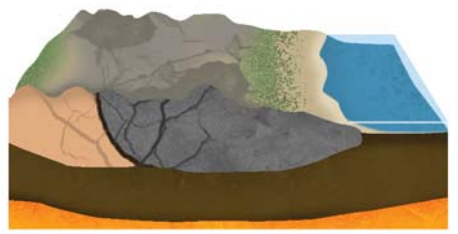

F: Orogen

Fig. 3. Schematic overview of the Wilson Cycle. The different blocks show a schematic overview of the development and closure of an ocean basin. Annotations refer to environments where black shales may accumulate and to processes that intervene in the formation of black shales. shales is largely independent of palaeolatitude but instead related to the distribution of continental masses (Irving et al., 1974; their Figs. 7-9; Klemme and Ulmishek, 1991). Thus, whilst climate and oceanography influence the local processes that determine whether black shales are deposited or not and also the stratigraphic development of successions, the basal framework imposed by plate tectonics determines where these processes may leave a black shale record.

The effects of plate tectonics on the physical surface of the Earth and on exogenic cycles are complex and nonlinear. Nevertheless, it has long been recognised that plate tectonics has the potential to effect changes in climate (cf. Chamberlin, 1897), on both short and long timescales, and that plate tectonics results in changes in the geography of the Earth that lead to the evolution of depositional environments (cf. Chamberlin, 1909; Wilson, 1968). Correlations have been proposed between the supercontinent cycle, superplume events, black shale deposition and other geological anomalies (e.g. Sheridan, 1987; Larson, 1991; Sinton and Duncan, 1997; Kerr, 1998; Condie, 2004; Katz et al., 2005). These studies represent major leaps forward in our understanding of the temporal distribution of Phanerozoic black shales. They provide possible answers to the stratigraphic clustering of black shales in specific stratigraphic intervals of the Phanerozoic (Klemme and Ulmishek, 1991).

In this paper, we focus on plate tectonic processes as drivers of the development of environments in which black shales may be deposited. We describe a relation between ocean basin evolution and black shale deposition, i.e. between the Wilson Cycle and organic matter-rich sedimentation (Table 1), contributing to an improved understanding of the temporal and geographical distribution of black shales and the variety of environments in which they form.

\section{Existing depositional models for ancient black shales}

Three depositional models based on modern analogues are traditionally used to summarise the range of environments in which black shales can accumulate: the restricted circulation model, the open ocean model, and the continental shelf model (Thiede and van Andel, 1977; Didyk et al., 1978; Tourtelot, 1979; Arthur and Sageman, 1994; Brumsack, 2006; Algeo and Rowe, 2011). The "restricted circulation model" is the oldest conception of how black shales are formed and arose from early study of the Black Sea by authors who envisaged it as a modern analogue for ancient environments of black shale deposition (e.g. Pompeckj, 1901). It has greatly influenced geological thinking on the subject of organic matter-rich sedimentation. Ironically, it is probably the least useful of the three because it imposes such extreme requirements on the deposition of black shales that the Black Sea is probably only a good analogue for the Black Sea (cf. Tyson, 2005). It is more useful to adapt this model and rename it "restricted basin model". This derivation of 
the traditional "restricted circulation model" retains the restricted physiography of the basin and its large depth-towidth ratio, but sheds the requirement that circulation be sluggish. Thus, basins that share such physical characteristics, but are not necessarily characterised by stably stratified water masses or by a euxinic water column, fall within this model. As a consequence, the Mediterranean falls within the "restricted basin model". Variations of this model have been proposed in the literature: (i) the deep, enclosed basin with a positive water balance (e.g. Caspers, 1957), (ii) the deep marginal basin impinged on by an oxygen minimum zone (e.g. Hülsemann and Emery, 1961), and (iii) the shallow stratified basin (e.g. Goldman, 1924), all three having in common an estuarine circulation (Brongersma-Sanders, 1971).

In the 1970s, as sediments from the bottom of ocean basins were sampled by the Deep Sea Drilling Project, it became apparent that certain stratigraphic intervals in the Mesozoic contain "widespread" black shales and that a solely bathymetric explanation for black shale depositional environments (e.g. Hallam and Bradshaw, 1979) was insufficient (cf. Weissert, 1981). These new data led many geoscientists to the conclusion that black shales were deposited globally and synchronously within narrow time envelopes, which were termed oceanic anoxic events (OAEs) (Schlanger and Jenkyns, 1976; Fischer and Arthur, 1977). Whilst it is clear that sediments in the marine realm during these time intervals were more prone to be rich in organic matter (Fischer, 1981), there is no reason to attempt to explain all coeval black shale occurrences by one model (e.g. Twenhofel, 1939; Arthur et al., 1990; Arthur and Sageman, 1994). Sedimentary processes and environments associated with coeval, but often petrologically different (Fig. 2) black shales, can differ significantly (e.g. Stow et al., 2001; Trabucho-Alexandre et al., 2011). Nevertheless, emphasis was placed on the chemical characteristics of seawater (Didyk et al., 1978), especially on oxygen depletion (but cf. Pedersen and Calvert, 1990 and the reply by Demaison, 1991). The open ocean model (e.g. Fischer and Arthur, 1977), which was proposed to explain widespread occurrence of black shales, includes many different environments, the only point in common being the location in the ocean and oxygen depletion of seawater. Therefore, this model is an oversimplification of the variety of environments and processes that may lead to an enrichment of organic matter in marine sediments (e.g. Stow et al., 2001). Furthermore, some ancient environments of black shale deposition in the open ocean, e.g. submarine seamounts below upwelling zones (Tourtelot, 1979; White, 1979), are absent in the modern ocean.

Modern shelves are fairly unique in geological history, being the product of the fast sea level rise after the last ice age, two orders of magnitude faster than during the Cretaceous (Schlager, 1981). The continental shelf model, which is therefore the least uniformitarian of the three (Emery, 1968), is commonly interpreted invoking nonuniformitarian shelf processes, e.g. permanent stable stratification of the water column over the shelf and the absence of bottom currents. Moreover, marine environments on continental crust are not limited to ancient pericontinental shelf and extensive epicontinental seas, but have included flooded continental rifts and pericontinental shelves of varying areal extent (Bradley, 2008). Whereas many depositional environments are nonuniformitarian because they are absent in the presentday tectonic configuration, exogenic processes - at least in the Phanerozoic - are in all likelihood uniformitarian, although certain evolutionary trends (cf. Davies et al., 2011) have led to changes in the response to these processes.

The problem of a uniformitarian interpretation of black shale deposition is that it limits the choice of analogue environments to those available in the present-day tectonogeographical configuration. The realisation of this "noanalogue" problem is not new (Arthur and Sageman, 1994), and it is widely acknowledged that the extensive ancient epicontinental seas have no equivalent in the modern world. In spite of this realisation, the interpretation of ancient black shale depositional environments has not been subject to critical reevaluation.

\section{The Wilson Cycle as a comprehensive depositional model for Phanerozoic black shales}

Wilson $(1966,1968)$ described the life cycle of ocean basins (Fig. 3a-f) and noted that each stage is associated with particular rock types and structures, but did not mention black shales. Black shales, the product of an optimal combination of production, concentration and preservation of organic matter (Bohacs et al., 2000; Tyson, 2005), have been deposited in a variety of subaqueous environments, including, but not limited to: (i) lakes and shallow epicontinental seas in continental rift settings (Fig. 3a, b), (ii) shallow epicontinental seas on flooded landmasses during transgressions and eustatic highstands (Fig. 3c), (iii) shallow pericontinental seas, particularly on the outer shelf, in association with transgressions and upwelling (Fig. 3c), (iv) the mesopelagic to upper bathyal portion of the continental slope and seamounts associated with the impingement of the oxygen minimum layer (cf. Wyrtki, 1962) on the seafloor, often in association with upwelling of nutrient-rich waters and (v) the deep seafloor of basins as a result of transport by turbidity currents.

\subsection{Continental rift}

Continental rifting is the earliest stage in ocean basin formation (Fig. 3a). During the continental rift phase, sedimentation in a basin is mostly terrestrial. Lakes may be created in depressions along the rift axis, and such lakes can be very deep and alkaline (e.g. East African Rift lakes). Sedimentation in lacustrine systems is extremely sensitive to climate (Bohacs et al., 2000). If winter temperatures do 
not reach freezing, the bottoms of these lakes are typically oxygen deficient, and, on their bottom, organic matter-rich, anoxic mud can accumulate. The Lower Permian Whitehill Formation (South Africa) contains lacustrine black shales with oil-prone kerogens that are thought to originate from the accumulation of freshwater algae under anoxic, fresh to brackish water conditions in a protorift basin in southwestern Gondwana (Faure and Cole, 1999). Occasional marine incursions allowed sulphate reduction and pyrite formation in these environments (Peters et al., 2005). Carboniferous lacustrine shales have also been deposited in the final stages of a synrift sequence of east Greenland (Ziegler, 1988; Stemmerik et al., 1990). The oldest Mesozoic source rocks in the South Atlantic are probably those in the North Falkland Basin (Richards and Hillier, 2000): early synrift fluvial and lacustrine rocks (cf. Caroll and Bohacs, 1999), which are relatively organic matter-rich even though the organic matter is poorly preserved, and late synrift lacustrine deposits, which are more organic matter-rich and reflect the transition from marginal marine to fully open-marine conditions (Peters et al., 2005).

As the rift matures, intrusion of seawater into the fracture system may occur (Fig. 3b); depending on regional climate, evaporitic or restricted marine sedimentation takes place in the flooded continental rift (Hay, 1981; Hay et al., 1981). Though emphasis here is on first-order tectonic controls on sedimentation, the role of regional climate must not be downplayed. Regional climate is primarily defined by zonal climate belts, and, in the course of Earth's history, basins migrated through these belts leading to changes in sedimentation patterns (Brongersma-Sanders, 1965; Wilde et al., 1997; Berry, 2010). Together with eustasy and tectonics, climate is a major allocyclic control on sediment supply and sedimentation (Cecil, 2003). Moreover, over long periods, climate is strongly controlled by tectonics because $\mathrm{CO}_{2}$ is controlled by "diastrophism", or plate tectonics (e.g. Chamberlin, 1897, 1909; cf. Berner, 1991).

Marine deposits in flooded continental rift settings may alternate with marginal terrigenous material transported by turbidity currents towards the basin centre. In proximal settings of the graben, where fan deltas build out, black shale formation will in general be suppressed as dilution inhibits organic enrichment of the sediments. However, in sediment-starved settings associated with rapid differential subsidence and arid or geomorphologically subdued hinterlands (Ravnås and Steel, 1998), or associated with rift shoulder morphologies conducive to sediment transport away from the basin, the deposition of source rocks with type I/II kerogen may occur if water depth, connectivity with the open ocean and regional climate favour estuarine circulation (Fig. 3b), which brings nutrients into the epicontinental basin. Examples of black shale accumulation due to invasion of a continental rift by marine waters are abundant, and these black shales are commonly excellent source rocks. The Permian Kupferschiefer of northern Europe, for instance, was deposited dur- ing active block faulting and the initial stages of marine transgression in relatively shallow water depth (BrongersmaSanders, 1965), after which salt was deposited. The Toarcian and the Kimmeridgian of the North Sea area, an aulacogen where no oceanic crust was generated, are good examples of unusually organic matter-rich marine black shales deposited in a continental rift setting. Toarcian and Kimmeridgian black shales are found in onshore, gentle sags, e.g. the Cleveland Basin (Powell, 2010), and offshore in deeper (ca. $100 \mathrm{~m}$ ) grabens, e.g. the Central Graben and the Dutch Central Graben. These grabens are subbasins created by crustal extension within the epicontinental shelf sea wherein the preservation of organic material was favoured. In the Far East, after widespread Palaeogene rifting with corresponding terrestrial sedimentation, an Early Miocene transgressive pulse flooded rift basins: Oligocene black shales were mainly deposited in lacustrine and fluvio-lacustrine environments within rift basins and contain oil-prone kerogens (e.g. offshore Vietnam), whereas Miocene black shales are gas-prone and were deposited in deltaic facies built out over continental margins (Petersen et al., 2001; Peters et al., 2005).

Lakes in continental rift settings may be regarded as a special case of the "restricted basin model" of black shale deposition. However, as Bohacs et al. (2000) noted, lakes differ from marine basins in several important ways therefore making it inappropriate to apply one unmodified model to all restricted basin systems. Shallow epicontinental seas in continental rift settings may be regarded as a "restricted basin" and also as a "continental shelf". Both depositional models may encompass processes capable of explaining a number of characteristics of black shales deposited in these settings. However, they are probably best interpreted as a specific type of environment separate of other also shallow and restricted settings.

\subsection{Juvenile spreading centre and expanding ocean}

Continued extension results in juvenile oceanic spreading centres. During the early, sediment-starved stages of this phase, shelves are underdeveloped as some time is required for the development of drainage networks and the accumulation of marginal strata (Ravnås and Steel, 1998; Bradley, 2008). Offshore, the shallow, young basin may experience black shale deposition if environmental conditions are favourable, a positive water balance, for instance. If the conditions are warm and arid, evaporite and carbonate deposition dominate the facies association (Hay, 1981). This black shale accumulation setting is similar to that previously described for a flooded continental rift. Marine black shales deposited under conditions of restricted water circulation (Zimmerman et al., 1987) were formed when Gondwana pulled apart during the Late Jurassic and accommodation increased episodically along the rift axis. A series of lakes (Fig. 3a) formed and gave rise to source rocks in both West 
Africa and Brazil (Peters et al., 2005). Clastic deposition became dominant during the Cenomanian as the basins between the South Atlantic continental masses deepened with increasing plate separation. The conditions that favoured black shale deposition were maintained until the Late Cretaceous when continued spreading led to the establishment of a deep connection with the North Atlantic allowing meridional circulation of ocean water and the ventilation of bottom waters in both basins (van Andel et al., 1977; Topper et al., 2011).

As seafloor spreading results in an expanding ocean, the basin changes from a narrow, landlocked state to a more open ocean state (Fig. 3c). In general, landlocked basins have a more terrigenous character than more open basins and hence neritic black shales deposited during the early stages of this phase are typically land-sourced and hence more gas-prone, whereas black shales deposited during later stages are more pelagic algal sourced and oil-prone. Palaeogeography and regional climate impose a second control on the nature of the sediments deposited in a basin. The two end-members may occur concomitantly in a single basin such as, for instance, in the mid-Cretaceous North Atlantic (Tissot et al., 1980; Summerhayes, 1981), with gas-prone western and oilprone southern and eastern margins.

As the basin deepens, black shale deposition transits from the bottom of the basin, previously relatively shallow, onto the seafloor of the growing continental shelves. The reason behind this relocation of black shale formation is related to the increasing transit paths to the seafloor as water depths increase in the expanding and subsiding basin as well as to the increasing volume of subthermocline water. Anoxia in the open ocean is unlikely due to the large mass of subthermocline water (Wignall and Newton, 2001). Overturning circulation, largely driven by extremes of surface temperature and salinity, and stirring by wind and tides (e.g. Ledwell et al., 2000), promotes an effective ventilation of the entire water column, and, in combination with the long settling times of particulate material from the euphotic zone to the seafloor, preservation of organic matter is very low. Nevertheless, slope instability processes, especially in organic matter-rich successions where diagenetic gas generation within slope sediments is an additional factor, may promote the transfer of part of the organic matter-rich sediments towards deeper, more distal settings where they are preserved as fine-grained, organic matter-rich turbidites (Degens et al., 1986; Stow et al., 2001; Trabucho-Alexandre et al., 2011). Examples of such turbidites may be found as deep sea Cretaceous black shales in the northern North Atlantic (e.g. ODP Site 1276) (Trabucho-Alexandre et al., 2011) and in the Mariana Basin in the Pacific Ocean (DSDP Site 585) (Whitman et al., 1985; Premoli Silva and Sliter, 1986).

Rapid sinking of the margins and the drowning of topography generally follow the early, sediment-starved stage. As the rift margins cool and subside, a large volume of sediment is eroded from areas peripheral to the rift. These sediments are deposited on the margins forming a buildup of thick seaward-prograding sediment wedges resulting in the shelf, slope and rise submarine topography characteristic of mature passive margins. As terrigenous sediment input increases, dilution overrides black shale development until the shelves have become more mature and a decrease in sediment supply occurs or, alternatively, until a rise of base level occurs. In the latter case, the base of the transgressive systems tract will typically be organic matter-rich above the transgressive ravinement surface in more offshore shelf settings and, with continued sea level rise, the maximum flooding surface may also be typified by black shale deposition (cf. Wignall, 1994). Gas-prone black shales may be deposited during the prograding stage of passive margins in paralic environments of siliciclastic coasts - such as deltas - without the requirements presented above for oil-prone, neritic black shales. It should be noted that sediment supply to the shelf is not evenly distributed but consists rather of a series of point sources, i.e. the river mouths, which can fill in the shelf locally whilst most of the shelf remains sediment starved (Hay and Southam, 1977; Hay, 1981). Once the local area is filled in, or if base level is lowered, discharge may occur over the shelf break, as in the case of the present-day Mississippi.

Sea level oscillations, which are also related to climate, exert an important control on marine sedimentation because the presence, size and distribution of marine subenvironments depend on sea level and also because the distribution of sedimentary facies in the marine realm is partly controlled by sea level stand, especially at shallower water depths where sea level oscillations have the greatest effect. High sea level stands lead to the flooding of continental crust and thereby to the creation of extensive peri- and epicontinental seas, shallow stratified basins (e.g. estuaries, fjords), lagoons and tidal flats (e.g. Twenhofel, 1915; Goldman, 1924; Wignall, 1991). At present, most export production is concentrated along the continental margins (Walsh, 1991; Laws et al., 2000), where up to $90 \%$ of organic carbon burial takes place (Hedges and Keil, 1995). Black shale deposition in the geological past is thus expected to have been favoured when shallow seas surrounded and extended into (Fig. 3c) continental masses (Potter et al., 1980; Mann et al., 2003) leading to the creation of various subenvironments in which organic matter accumulation was favoured. Such a scenario is associated with supercontinent breakup and the onset of the Wilson Cycle because newly formed oceanic crust is thermally buoyant and hence the global ocean basin volume decreases leading to transgressive pulses (e.g. Hays and Pitman, 1973; Pitman, 1978; Cogné et al., 2006).

It is therefore unsurprising that the vast majority of ancient coeval black shale deposits are found on ancient peri- and epicontinental settings. Widespread black shale deposition in the Cretaceous, for example, is a reflection of the opening of modern ocean basins and the maturation of their passive margins as well as a consequence of the mid-Cretaceous superplume and eustatic sea level high (e.g. Larson, 1991). In the mid-Cretaceous, extensive epicontinental seas along the 
Tethyan seaway and the pericontinental seas on the young continental shelves of the North and South Atlantic experienced significant organic matter-rich sedimentation (van Andel et al., 1977; Kuhnt and Wiedmann, 1995; Lüning et al., 2004; Emeis and Weissert, 2009). The extent of black shale deposition and the nature of the organic matter depended on palaeogeographical setting and on climate and palaeoceanography (Kuhnt and Wiedmann, 1995; Jímenez Berrocoso et al., 2010; Trabucho-Alexandre et al., 2010; Hofmann and Wagner, 2011; MacLeod et al., 2011; TrabuchoAlexandre et al., 2011). In general, marine organic matter is restricted to sequences of the southern North Atlantic and the margins of the adjacent Western Tethys and becomes more widespread in the uppermost Cenomanian/Turonian (Tissot et al., 1980; Summerhayes, 1981; Kuhnt and Wiedmann, 1995). In much of the North Atlantic, pre-Cenomanian rocks typically have low TOC $(<1 \%)$ dominated by terrigenous plant debris (Summerhayes, 1981). During the Cenomanian, organic matter richness increased and reached a maximum near the Cenomanian/Turonian boundary (OAE 2) with TOC up to $40 \%$. These organic matter-rich rocks commonly represent three different depositional settings: shelf shales and marls, continental margin marls and deep water shales and organic matter-rich silt- and sandstones (turbidites). Organic matter-rich sedimentation persisted beyond the Cenomanian/Turonian at certain shelf localities, e.g. northern South America, due to the estuarine circulation and upwelling (Trabucho-Alexandre et al., 2010; Topper et al., 2011). Black shale deposition in the rest of the basin was discontinued after the opening of the Equatorial Atlantic Seaway to deep water circulation (Topper et al., 2011).

Several environments of black shale accumulation are associated with an expanding ocean. The most significant are those located on epi- and pericontinental shelves. Even though both may be summarised by the traditional "continental shelf model", the processes that lead to black shale formation in these environments and the geographical extent of organic matter-rich facies and their marine or terrigenous character, amongst other characteristics, (partly) depend on tectonic setting. Thus, black shale successions deposited in onshore sags, fjords and estuaries, and tidal flats will exhibit different characteristics which are the result of the different processes and environments that led to their formation. Accumulation of organic matter-rich sediments on the deep seafloor, commonly related to resedimentation processes transporting shelf and slope material to the deep sea (Degens et al., 1986; Stow et al., 2001), is typically related to the early stages of ocean basin opening and does not fall under any of the three existing depositional models - although the presence of these resedimented materials is sometimes erroneously interpreted in the light of the "restricted circulation model". Existing evidence shows that sediments deposited by pelagic settling on the deep, abyssal seafloor, even during OAEs, are organic matter-lean (Heezen et al., 1973; Takashima et al., 2011).

\subsection{Mature ocean basin and closure}

Widespread black shale deposition is not favoured in mature ocean basins because their thermally subsided seafloor is very deep and their active continental margins (shelves) very narrow (Fig. 3d). Furthermore, during agglomeration of continents, i.e. the late stages of the Wilson Cycle, less submarine volcanism occurs and sea level falls; consequently, fewer nutrients are added to the system. Moreover, due to a reduced surface area of shelf seas, the dissipation of tidal energy in the open ocean increases with consequent improved vertical mixing (de Boer and Trabucho-Alexandre, 2011). Therefore, the development of organic matter-rich sediments is inhibited. Nevertheless, black shales may still be deposited under regions of enhanced upwelling, such as the eastern margins of the basin (e.g. present-day Peru), or in silled marginal basins (e.g. Gulf of California) (e.g. Hülsemann and Emery, 1961; Demaison and Moore, 1980). Coastlines with upwelling tend to be arid (Brongersma-Sanders, 1971); the lack of vegetation on land reinforces the oil-prone character of black shales deposited on continental shelves under zones of intense upwelling. Aridity limits the dilution of organic matter by terrigenous material while at the same time stimulating productivity by aeolian fertilisation of the euphotic zone (e.g. Jickells et al., 2005). Silurian black shales deposited on the southern passive margin of the Rheic Ocean (North Africa and Middle East) consist of graptolitic shales with abundant organic matter related to blooms of marine prasinophytes (Tyson, 1994). The deposition of these shales took place during a high sea level stand in a mature ocean basin with wide shelves located at $45-55^{\circ} \mathrm{S}$ under an upwelling zone (Parrish, 1982; Tissot et al., 1984; Klemme and Ulmishek, 1991; Lüning et al., 2000; Peters et al., 2005; Cramer and Saltzman, 2007). Late Devonian algal-rich black shales, which were deposited at high southern latitudes along the western margin of Gondwana (Brazil and Bolivia) under an upwelling zone, are a further example of black shale deposition on the margins of a mature ocean basin. It should be noted that, in both examples, land plants had not yet or were only poorly developed at that time (Davies et al., 2011).

The terminal stages of the Wilson Cycle are characterised by significant constriction of the basin, which becomes a landlocked marginal basin (Fig. 3d). During this phase, black shales may be deposited as a consequence of estuarine circulation patterns (Brongersma-Sanders, 1971) which, in turn, depend on the location of the basin with respect to zonal climate belts. Examples of this type of black shale development are the Neogene Mediterranean sapropels and the Holocene Black Sea. Examples of black shales deposited in marginal basins include the San Joaquin and offshore California and Caspian basins. These basins contain thick, dominantly marine diatomaceous source rocks of Miocene age, which was the last Phanerozoic interval of major source rock deposition (Peters et al., 2005). During the Ordovician-Silurian, black shale deposition on the margins 
of the narrow, closing Iapetus Ocean (Europe; Fig. 3e) took place at tropical latitudes on a drowned carbonate shelf (Leggett, 1978; Klemme and Ulmishek, 1991).

The final stages in the Wilson Cycle, i.e. subduction, closure of an ocean basin and orogeny, lead to the creation of foreland basins. When mountains are built through the closure of an ocean basin, tectonic loading of the crust during incremental growth of the orogen leads to the creation of accommodation space on both sides of the orogen (Ettensohn, 2008). Accommodation space creation is initially very rapid, and shallow transgressive seas move across the basin. However, because no major subaerial source of sediment is available to fill the basin, sediment starvation characterises the initial stages of foreland basins. Mud and organic matter in the water column comprise the main sediment input, accumulate on the basin floor and may be preserved as black shales. This situation is typical of retroarc foreland basins (e.g. Appalachian Basin), which are floored by continental crust. Black shales deposited during the Devonian and Permian in basins west of the Appalachian Mountains (Ettensohn, 2008) reflect deposition in a foreland basin (Fig. 3e) during the closure of the Iapetus and Rheic oceans. As subaerial relief is formed, however, black shales are no longer developed due to increased dilution by coarse siliciclastic sediments. Peripheral foreland basins, which are located on the plate margin being consumed, have a different situation and receive large volumes of clastic sediment that form thick, flysch-like sequences.

\section{Conclusions}

Sedimentation is intimately associated with basin development. Wilson, a pioneer in the development of the Theory of Plate Tectonics, noted that each stage in ocean basin development has its own characteristic rock types. Ancient black shales, which are the source rocks of most of the world's known oil reserves, were deposited in different sedimentary environments created at various stages of the Wilson Cycle. Even though black shales may be deposited in different environments at any stage of the Wilson Cycle, their petrological characteristics and the processes that have led to their formation vary considerably. Indeed, the term "black shale" is useful when referring to organic matter-rich sedimentary rocks in general, but it should not be forgotten that it is a collective noun that groups rocks with very different origins. The spatial distribution of environments of black shale deposition is controlled by the basal framework of plate tectonics. Black shale deposition and the architecture of black shale deposits in these environments are controlled by climate, oceanography and basin evolution, the latter controlling the development of subenvironments in which black shales may accumulate as well as (partly) controlling the former two. Furthermore, tectonic setting (partly) controls the type of black shale, their stratigraphic and geographical extent and their position in the basin infill sequence. Correlation of coeval "black shales" without taking into account their sedimentological characteristics, the local processes that led to their formation and the environments in which they were deposited is likely to lead to unsound palaeoenvironmental interpretations.

Conceptual models and modern analogues help in the interpretation of ancient black shale successions. However, uniformitarian, oversimplified models actually present a barrier to the interpretation of environments of black shale accumulation because they are commonly simple, static, oceanographical models that do not take into account two very important variables: (i) the tectonic setting and evolution of a basin and (ii) changing regional climate due to lithospheric plate migration. A successful interpretation of ancient environments of black shale accumulation must have its foundations on these two variables upon which oceanographical interpretations can then be superimposed. Understanding why black shales were more widespread during specific time intervals in the Phanerozoic is very important. However, the fact that black shales are coeval does not mean that similar processes produced them, or that depositional environments were similar; rather, each black shale should be interpreted individually after which a meaningful correlation in terms of processes may be achieved.

Acknowledgements. This project was funded by Senter-Novem. Nikki Bos is thanked for making the Wilson Cycle figures. Reishi Takashima is thanked for providing part of the data presented in Fig. 1. The authors thank Karl Föllmi and Paul Th. Meijer for commenting on an earlier version of the manuscript. The editor, Darren Gröcke, and the reviewers, Álvaro Jímenez Berrocoso, Thomas Wagner and Paul Wignall are thanked for their comments and suggestions.

Special Issue: "Phanerozoic black shales and oceanic anoxic events: geochemistry, sedimentology and stratigraphy"

Edited by: J. Trabucho-Alexandre, P. L. de Boer, and D. R. Gröcke

\section{References}

Algeo, T. J. and Rowe, H.: Paleoceanographic applications of trace-metal concentration data, Chem. Geol., doi:10.1016/j.chemgeo.2011.09.002, in press, 2011.

Arthur, M. A.: North Atlantic Cretaceous black shales: the record at Site 398 and a brief comparison with other occurrences, in: Initial Rep. Deep Sea, edited by: Sibuet, J.-C., Ryan, W. B. F., Arthur, M. A., Barnes, R. O., Habib, D., Iaccarino, S., Johnson, D., Lopatin, B., Maldonado, A., Moore, D. G., Morgan, G. E., Réhault, J.-P., Sigal, J., and Williams, C. A., US Govt Printing Office, Washington, 47(2), 719-751, 1979.

Arthur, M. A. and Sageman, B. B.: Marine black shales: depositional mechanisms and environments of ancient deposits, Annu. Rev. Earth Pl. Sc., 22, 499-551, 1994.

Arthur, M. A. and Sageman, B. B.: Sea-level control on sourcerock development: perspectives from the Holocene Black Sea, the mid-Cretaceous Western Interior Basin of North America, 
and the Late Devonian Appalachian Basin, in: The deposition of organic-carbon-rich sediments: models, mechanisms, and consequences, edited by: Harris, N. B., SEPM Spec. P., 82, 35-59, 2005.

Arthur, M. A., Jenkyns, H. C., Brumsack, H.-J., and Schlanger, S. O.: Stratigraphy, geochemistry, and paleoceanography of organic carbon-rich Cretaceous sequences, in: Cretaceous resources, events and rhythms. Background and plans for research, edited by: Ginsburg, R. N. and Beaudoin, B., NATO ASI Series C, Kluwer Academic Publishers, Dordrecht, 304, 75-119, 1990.

Berner, R. A.: A model for atmospheric $\mathrm{CO}_{2}$ over Phanerozoic time, Am. J. Sci., 291, 339-376, 1991.

Berner, R. A.: GEOCARBSULF: A combined model for Phanerozoic atmospheric $\mathrm{O}_{2}$ and $\mathrm{CO}_{2}$, Geochim. Cosmochim. Ac., 70, 5653-5664, 2006.

Berner, R. A., Lasaga, A. C., and Garrels, R. M.: The carbonatesilicate geochemical cycle and its effect on atmospheric carbon dioxide over the past 100 million years, Am. J. Sci., 283, 641683, 1983.

Berry, W. B. N.: Black shales: an Ordovician perspective, Geol. S. Am. S., 466, 141-147, 2010.

Bohacs, K. M., Carroll, A. R., Neal, J. E., and Mankiewicz, P. J.: Lake-basin type, source potential, and hydrocarbon character: an integrated sequence-stratigraphic-geochemical framework, in: Lake basins through space and time, edited by: GierlowskiKordesch, E. H. and Kelts, K. R., AAPG Stud. Geol., 46, 3-34, 2000.

Bradley, D. C.: Passive margins through earth history, Earth-Sci. Rev., 91, 1-26, 2008.

Brongersma-Sanders, M.: Metals of Kupferschiefer supplied by normal sea water, Geol. Rundsch., 55, 365-375, 1965.

Brongersma-Sanders, M.: Origin of major cyclicity of evaporites and bituminous rocks: an actualistic model, Mar. Geol., 11, 123144, 1971.

Brumsack, H. J.: The trace metal content of recent organic carbonrich sediments: Implications for Cretaceous black shale formation, Palaeogeogr. Palaeocl., 232, 344-361, 2006.

Caroll, A. R. and Bohacs, K. M.: Stratigraphic classification of ancient lakes: balancing tectonic and climate controls, Geology, 27, 99-102, 1999.

Caspers, H.: Black Sea and the Sea of Azov, in: Treatise of Marine Ecology and Paleoecology, edited by: Hedgepeth, J., Geol. Soc. Am. Mem., 67, 801-890, 1957.

Cecil, C. B.: The concept of autocyclic and allocyclic controls on sedimentation and stratigraphy, emphasizing the climate variable, in: Climate controls on stratigraphy, edited by: Cecil, C. B. and Edgar, N. T., SEPM Spec. P., 77, 13-20, 2003.

Chamberlin, T. C.: A group of hypotheses bearing on climatic changes, J. Geol., 5, 653-683, 1897.

Chamberlin, T. C.: Diastrophism as the ultimate basis of correlation, J. Geol., 17, 685-693, 1909.

Cogné, J. P., Humler, E., and Courtillot, V.: Mean age of oceanic lithosphere drives eustatic sea-level change since Pangea breakup, Earth Planet. Sc. Lett., 245, 115-122, 2006.

Condie, K. C.: Supercontinents and superplume events: distinguishing signals in the geologic record, Phys. Earth Planet. In., 146, 319-332, 2004.

Cramer, B. D. and Saltzman, M. R.: Fluctuations in epeiric sea carbonate production during Silurian positive carbon isotope excur- sions: a review of proposed paleoceanographic models, Palaeogeogr. Palaeocl., 245, 37-45, 2007.

Creaney, S. and Passey, Q. R.: Recurring patterns of total organic carbon and source rock quality within a sequence stratigraphic framework, AAPG Bull., 77, 386-401, 1993.

Davies, N. S., Gibling, M. R., and Rygel, M. C.: Alluvial facies evolution during the Palaeozoic greening of the continents: case studies, conceptual models and modern analogues, Sedimentology, 58, 220-258, 2011.

de Boer, P. L. and Smith, D. G.: Orbital forcing and cyclic sequences, in: Orbital forcing and cyclic sequences, edited by: de Boer, P. L. and Smith, D. G., Int. As. Sed., 19, 1-14, 1994.

de Boer, P. L. and Trabucho-Alexandre, J.: Orbitally forced sedimentary rhythms in the stratigraphic record: is there room for tidal forcing?, Sedimentology, 59, 379-392, 2012.

Degens, E. T., Emeis, K.-C., Mycke, B., and Wiesner, M. G.: Turbidites, the principal mechanism yielding black shales in the early deep Atlantic Ocean, in: North Atlantic palaeoceanography, edited by: Summerhayes, C. P. and Shackleton, N. J., Geol. Soc. Spec. Publ., 21, 361-376, 1986.

Demaison, G. J.: Anoxia vs. productivity: what controls the formation of organic-carbon-rich sediments and sedimentary rocks?: Discussion, AAPG Bull., 75, 499, 1991.

Demaison, G. J. and Moore, G. T.: Anoxic environments and oil source bed genesis, AAPG Bull., 64, 1179-1209, 1980.

Dewey, J. F. and Burke, K.: Hot spots and continental break-up: implications for collisional orogeny, Geology, 2, 57-60, 1974.

Dickens, G. R., O’Neil, J. R., Rea, D. K., and Owen, R. M.: Dissociation of oceanic methane hydrate as a cause of the carbon isotope excursion at the end of the Paleocene, Paleoceanography, 10, 965-971, 1995.

Didyk, B. M., Simoneit, B. R. T., Brassell, S. C., and Eglinton, G.: Organic geochemical indicators of palaeoenvironmental conditions of sedimentation, Nature, 272, 216-222, 1978.

Emeis, K. C. and Weissert, H.: Tethyan-Mediterranean organic carbon-rich sediments from Mesozoic black shales to sapropels, Sedimentology, 56, 247-266, 2009.

Emery, K. O.: Relict sediments on continental shelves of world, AAPG Bull., 52, 445-464, 1968.

Ettensohn, F. R.: The Appalachian foreland basin in eastern United States, in: Sedimentary basins of the world, edited by: Andrew, D. M., 5, 105-179, 2008.

Faure, K. and Cole, D.: Geochemical evidence for lacustrine microbial blooms in the vast Permian Main Karoo, Paraná, Falkland Islands and Huab basins of southwestern Gondwana, Palaeogeogr. Palaeocl., 152, 189-213, 1999.

Fischer, A. G.: Climatic oscillations in the biosphere, in: Biotic crises in ecological and evolutionary time, edited by: Nitecki, M. H., Academic Press, New York, 103-131, 1981.

Fischer, A. G. and Arthur, M. A.: Secular variations in the pelagic realm, in: Deep-water carbonate environments, edited by: Cook, H. E. and Enos, P., SEPM Spec. P., 25, 19-50, 1977.

Frakes, L. A., Francis, J. E., and Syktus, J. I.: Climate modes of the Phanerozoic, Cambridge University Press, Cambridge, 274 pp., 1992.

Goldman, M. I.: "Black shale" formation in and about Chesapeake Bay, AAPG Bull., 8, 195-201, 1924.

Gradstein, F. M., Ogg, J. G., and Smith, A. G.: A geologic time scale 2004, Cambridge University Press, Cambridge, 589 pp., 
2004.

Hallam, A. and Bradshaw, M. J.: Bituminous shales and oolitic ironstones as indicators of transgressions and regressions, J. Geol Soc., 136, 157-164, 1979.

Haq, B. U. and Al-Qahtani, A. M.: Phanerozoic cycles of sea-level change on the Arabian Platform, GeoArabia, 10, 127-160, 2005.

Haq, B. U., Hardenbol, J., and Vail, P. R.: Chronology of fluctuating sea levels since the Triassic, Science, 235, 1156-1167, 1987.

Hay, W. W.: Sedimentological and geochemical trends resulting from the breakup of Pangaea, Oceanol. Acta, 4 (SP), 135-147, 1981.

Hay, W. W. and Southam, J. R.: Modulation of marine sedimentation by the continental shelves, in: The fate of fossil fuel $\mathrm{CO}_{2}$ in the oceans, edited by: Andresen, N. R. and Malahoff, A., Plenum Publishing Corporation, New York, 569-604, 1977.

Hay, W. W., Barron, E., Sloan, J., and Southam, J.: Continental drift and the global pattern of sedimentation, Geol. Rundsch., 70, 302-315, 1981.

Hays, J. D. and Pitman III, W. C.: Lithospheric plate motion, sea level changes and ecological consequences, Nature, 246, 18-22, 1973.

Hedges, J. I. and Keil, R. G.: Sedimentary organic matter preservation: an assessment and speculative synthesis, Mar. Chem., 49, 81-115, 1995.

Heezen, B. C., MacGregor, I. D., Foreman, H. P., Forristal, G., Hekel, H., Hesse, R., Hoskins, R. H., Jones, E. J. W., Kaneps, A., Krasheninnikov, V. A., Okada, H., and Ruef, M. H.: Diachronous deposits: a kinematic interpretation of the post Jurassic sedimentary sequence on the Pacific plate, Nature, 241, 25-32, 1973.

Hesselbo, S. P., Gröcke, D. R., Jenkyns, H. C., Bjerrum, C. J., Farrimond, P., Bell, H. S. M., and Green, O. R.: Massive dissociation of gas hydrate during a Jurassic oceanic anoxic event, Nature, 406, 392-395, 2000.

Hofmann, P. and Wagner, T.: ITCZ controls on Late Cretaceous black shale sedimentation in the tropical Atlantic Ocean, Paleoceanography, 26, PA4223, doi:10.1029/2011PA002154, 2011.

Hülsemann, J. and Emery, K. O.: Stratification in recent sediments of Santa Barbara Basin as controlled by organisms and water character, J. Geol., 69, 279-290, 1961.

Irving, E., North, F. K., and Couillard, R.: Oil, climate, and tectonics, Can. J. Earth Sci., 11, 1-17, 1974.

Jenkyns, H. C.: Cretaceous anoxic events: from continents to oceans, J. Geol. Soc. London, 137, 171-188, 1980.

Jickells, T. D., An, Z. S., Andersen, K. K., Baker, A. R., Bergametti, G., Brooks, N., Cao, J. J., Boyd, P. W., Duce, R. A., Hunter, K. A., Kawahata, H., Kubilay, N., laRoche, J., Liss, P. S., Mahowald, N., Prospero, J. M., Ridgwell, A. J., Tegen, I., and Torres, R.: Global iron connections between desert dust, ocean biogeochemistry, and climate, Science, 308, 67-71, 2005.

Jímenez Berrocoso, A., MacLeod, K. G., Martin, E. E., Bourbon, E., Londoño, C. I., and Basak, C.: Nutrient trap for Late Cretaceous organic-rich black shales in the tropical North Atlantic, Geology, 38, 1111-1114, 2010.

Katz, B. J.: Controlling factors on source rock development-a review of productivity, preservation, and sedimentation rate, in: The deposition of organic-carbon-rich sediments: models, mechanisms, and consequences, edited by: Harris, N. B., SEPM Spec. P., 82, 7-16, 2005.

Katz, M. E., Wright, J. D., Miller, K. G., Cramer, B. S., Fennel,
K., and Falkowski, P. G.: Biological overprint of the geological carbon cycle, Mar. Geol., 217, 323-338, 2005.

Kearey, P., Klepeis, K. A., and Vine, F. J.: Global tectonics, WileyBlackwell, Oxford, 496 pp., 2009.

Kerr, A. C.: Oceanic plateau formation: a cause of mass extinction and black shale deposition around the Cenomanian-Turonian boundary?, J. Geol. Soc. London, 155, 619-626, 1998.

Kidder, D. L. and Worsley, T. R.: Phanerozoic Large Igneous Provinces (LIPs), HEATT (Haline Euxinic Acidic Thermal Transgression) episodes, and mass extinctions, Palaeogeogr. Palaeocl., 295, 162-191, 2010.

Klemme, H. D. and Ulmishek, G. F.: Effective petroleum source rocks of the world: stratigraphic distribution and controlling depositional factors, AAPG Bull., 75, 1809-1851, 1991.

Kuhnt, W. and Wiedmann, J.: Cenomanian-Turonian source rocks: paleobiogeographic and paleoenvironmental aspects, in: Paleogeography, paleoclimate, and source rocks, edited by: Huc, A.Y., AAPG Stud. Geol., 40, 213-231, 1995.

Larson, R. L.: Geological consequences of superplumes, Geology, 19, 963-966, 1991.

Laws, E. A., Falkowski, P. G., Smith Jr., W. O., Ducklow, H., and McCarthy, J. J.: Temperature effects on export production in the open ocean, Global Biogeochem. Cy., 14, 1231-1246, 2000.

Ledwell, J., Montgomery, E., Polzin, K., Laurent, L., Schmitt, R., and Toole, J.: Evidence for enhanced mixing over rough topography in the abyssal ocean, Nature, 403, 179-182, 2000.

Leggett, J. K.: Eustacy and pelagic regimes in the Iapetus Ocean during the Ordovician and Silurian, Earth Planet. Sc. Lett., 41, 163-169, 1978.

Lüning, S., Craig, J., Loydell, D. K., Storch, P., and Fitches, B.: Lower Silurian "hot shales" in North Africa and Arabia: regional distribution and depositional model, Earth-Sci. Rev., 49, 121200, 2000.

Lüning, S., Kolonic, S., Belhadj, E. M., Belhadj, Z., Cota, L., Baric, G., and Wagner, T.: Integrated depositional model for the Cenomanian-Turonian organic-rich strata in North Africa, Earth-Sci. Rev., 64, 51-117, 2004.

MacLeod, K. G., Londoño, C. I., Martin, E. E., Jímenez Berrocoso, A., and Basak, C.: Changes in North Atlantic circulation at the end of the Cretaceous greenhouse interval, Nature Geosci., 4, 779-782, 2011.

Macquaker, J. H. S., Taylor, K. G., and Gawthorpe, R. L.: Highresolution facies analyses of mudstones: implications for paleoenvironmental and sequence stratigraphic interpretations of offshore ancient mud-dominated successions, J. Sediment. Res., 77, 324-339, 2007.

Macquaker, J. H. S., Bentley, S. J., and Bohacs, K. M.: Waveenhanced sediment-gravity flows and mud dispersal across continental shelves: reappraising sediment transport processes operating in ancient mudstone successions, Geology, 38, 947-950, 2010.

Mann, P., Gahagan, L., and Gordon, M. B.: Tectonic setting of the world's giant oil and gas fields, in: Giant oil and gas fields of the decade 1990-1999, edited by: Halbouty, M. T., AAPG Memoir, 78, 15-105, 2003.

McArthur, J. M.: Strontium isotope stratigraphy, in: Application of modern stratigraphic techniques: theory and case histories, edited by: Ratcliffe, K. T. and Zaitlin, B. A., SEPM Spec. P., 94, 129-142, 2010. 
McElwain, J. C., Wade-Murphy, J., and Hesselbo, S. P.: Changes in carbon dioxide during an oceanic anoxic event linked to intrusion into Gondwana coals, Nature, 435, 479-482, 2005.

Miller, K. G., Kominz, M. A., Browning, J. V., Wright, J. D., Mountain, G. S., Katz, M. E., Sugarman, P. J., Cramer, B. S., ChristieBlick, N., and Pekar, S. F.: The Phanerozoic record of global sea-level change, Science, 310, 1293-1298, 2005.

Ogg, J. G., Ogg, G., and Gradstein, F. M.: The concise geologic time scale, Cambridge University Press, Cambridge, 177 pp., 2008.

Otis, R. M. and Schneidermann, N.: A process for evaluating exploration prospects, AAPG Bull., 81, 1087-1109, 1997.

Parrish, J. T.: Upwelling and petroleum source beds, with reference to Paleozoic, AAPG Bull., 66, 750-774, 1982.

Pedersen, T. F. and Calvert, S. E.: Anoxia vs. productivity: what controls the formation of organic-carbon-rich sediments and sedimentary rocks?, AAPG Bull., 74, 454-466, 1990.

Peters, K. E., Walters, C. C., and Moldowan, J. M.: The biomarker guide. Volume 2. Biomarkers and isotopes in petroleum exploration and Earth history, Cambridge University Press, Cambridge, 1155 pp., 2005.

Petersen, H. I., Andersen, C., Anh, P. H., Bojesen-Koefoed, J. A., Nielsen, L. H., Nytoft, H. P., Rosenberg, P., and Thanh, L.: Petroleum potential of Oligocene lacustrine mudstones and coals at Dong Ho, Vietnam - an outcrop analogue to terrestrial source rocks in the greater Song Hong Basin, J. Asian Earth Sci., 19, 135-154, 2001.

Piper, D. Z. and Calvert, S. E.: A marine biogeochemical perspective on black shale deposition, Earth-Sci. Rev., 95, 63-96, 2009.

Pitman III, W. C.: Relationship between eustacy and stratigraphic sequences of passive margins, Geol. Soc. Am. Bull., 89, 13891403, 1978.

Pompeckj, J. F.: Die Juraablagerungen zwischen Regensburg und Regenstauf, Geogn. Jahrb., 14, 139-220, 1901.

Potter, P. E., Maynard, J. B., and Pryor, W. A.: Sedimentology of shale. Study guide and reference source, Springer-Verlag, New York, 303 pp., 1980.

Powell, J. H.: Jurassic sedimentation in the Cleveland Basin: a review, P. Yorks. Geol. Soc., 58, 21-72, 2010.

Premoli Silva, I. and Sliter, W.: Late Aptian and CenomanianTuronian planktonic foraminifers from Deep Sea Drilling Project Site 585, Leg 89, East Mariana Basin, in: Initial Rep. Deep Sea, edited by: Moberly, R., Schlanger, S. O., Baltuck, M., Bergen, J. A., Dean, W., Floyd, P. A., Fujii, N., Haggerty, J. A., Ogg, J. G., Premoli Silva, I., Schaaf, A., Schaefer, R. G., Sliter, W. V., and Whitman, J. M., US Govt Printing Office, Washington, 89, 297-309, 1986.

Prokoph, A., Shields, G. A., and Veizer, J.: Compilation and timeseries analysis of a marine carbonate $\delta^{18} \mathrm{O}, \delta^{13} \mathrm{C},{ }^{87} \mathrm{Sr} /{ }^{86} \mathrm{Sr}$ and $\delta^{34} \mathrm{~S}$ database through Earth history, Earth-Sci. Rev., 87, 113133, 2008.

Raup, D. M. and Sepkoski, J. J.: Periodic extinction of families and genera, Science, 231, 833-836, 1986.

Ravnås, R. and Steel, R. J.: Architecture of marine rift-basin successions, AAPG Bull., 82, 110-146, 1998.

Raymo, M. E. and Ruddiman, W. F.: Tectonic forcing of late Cenozoic climate, Nature, 359, 117-122, 1992.

Richards, P. C. and Hillier, B. V.: Post-drilling analysis of the North Falkland Basin - Part 2: petroleum system and future prospects,
J. Petrol. Geol., 23, 273-292, 2000.

Ridgwell, A.: A Mid Mesozoic revolution in the regulation of ocean chemistry, Mar. Geol., 217, 339-357, 2005.

Rine, J. M. and Ginsburg, R. N.: Depositional facies of a mud shoreface in Suriname, South America - a mud analogue to sandy, shallow-marine deposits, J. Sediment. Petrol., 55, 633652, 1985.

Royer, D. L.: $\mathrm{CO}_{2}$-forced climate thresholds during the Phanerozoic, Geochim. Cosmochim. Ac., 70, 5665-5675, 2006.

Ryan, W. B. F. and Cita, M. B.: Ignorance concerning episodes of ocean-wide stagnation, Mar. Geol., 23, 197-215, 1977.

Scotese, C. R.: A continental drift flipbook, J. Geol., 112, 729-741, 2004.

Schieber, J.: Reverse engineering mother nature - shale sedimentology from an experimental perspective, Sed. Geol., 238, 1-22, 2011.

Schieber, J. and Southard, J. B.: Bedload transport of mud by floccule ripples - direct observation of ripple migration processes and their implications, Geology, 37, 483-486, 2009.

Schlager, W.: The paradox of drowned reefs and carbonate platforms, Geol. Soc. Am. Bull., 92, 197-211, 1981.

Schlanger, S. O. and Jenkyns, H. C.: Cretaceous oceanic anoxic events: causes and consequences, Geol. Mijnbouw, 55, 179-184, 1976.

Sheridan, R. E.: Pulsation tectonics as the control of long-term stratigraphic cycles, Paleoceanography, 2, 97-118, 1987.

Sinton, C. W. and Duncan, R. A.: Potential links between ocean plateau volcanism and global ocean anoxia at the CenomanianTuronian boundary, Econ. Geol., 92, 836-842, 1997.

Stanley, S. M.: Earth system history, W. H. Freeman and Company, New York, 615 pp., 1999.

Stemmerik, L., Christiansen, F., and Piasecki, S.: Carboniferous lacustrine shale in East Greenland - additional source rock in Northern North Atlantic?, in: Lacustrine basin exploration: case studies and modern analogs, edited by: Katz, B. J., AAPG Memoir, 50, 277-286, 1990.

Storey, M., Duncan, R. A., and Swisher, C. C.: Paleocene-Eocene Thermal Maximum and the opening of the northeast Atlantic, Science, 316, 587-589, 2007.

Stow, D. A. V., Huc, A.-Y., and Bertrand, P.: Depositional processes of black shales in deep water, Mar. Petrol. Geol., 18, 491-498, 2001.

Summerhayes, C. P.: Organic facies of Middle Cretaceous black shales in deep North Atlantic, AAPG Bull., 65, 2364-2380, 1981.

Takashima, R., Nishi, H., Yamanaka, T., Tomosugi, T., Fernando, A. G., Tanabe, K, Moriya, K., Kawabe, F., and Hayashi, K.: Prevailing oxic environments in the Pacific Ocean during the mid-Cretaceous Oceanic Anoxic Event 2, Nature Comm., 2, 234, doi:10.1038/ncomms1233, 2011.

Thiede, J. and van Andel, T. H.: The paleoenvironment of anaerobic sediments in the Late Mesozoic South Atlantic Ocean, Earth Planet. Sc. Lett., 33, 301-309, 1977.

Tissot, B.: Effects on prolific petroleum source rocks and major coal deposits caused by sea-level changes, Nature, 277, 463-465, 1979.

Tissot, B., Demaison, G. J., Masson, P., Delteil, J. R., and Combaz, A.: Paleoenvironment and petroleum potential of Middle Cretaceous black shales in Atlantic basins, AAPG Bull., 64, 2051- 
2063, 1980.

Tissot, B., Espitalié, J., Deroo, G., Tempere, C., and Jonathan, D.: Origin and migration of hydrocarbons in the eastern Sahara (Algeria), in: Petroleum geochemistry and basin evaluation, edited by: Demaison, G. and Murris, R. J., AAPG Memoir, 35, 315324, 1984

Topper, R. P. M., Trabucho-Alexandre, J., Tuenter, E., and Meijer, P. T.: A regional ocean circulation model for the mid-Cretaceous North Atlantic Basin: implications for black shale formation, Clim. Past, 7, 277-297, 2011, http://www.clim-past.net/7/277/2011/.

Tourtelot, H. A.: Black Shale - its deposition and diagenesis, Clays Clay Miner., 27, 313-321, 1979.

Trabucho-Alexandre, J., Tuenter, E., Henstra, G. A., van der Zwan, K. J., van de Wal, R. S. W., Dijkstra, H. A., and de Boer, P. L.: The mid-Cretaceous North Atlantic nutrient trap: Black shales and OAEs, Paleoceanography, 25, PA4201, doi:10.1029/2010PA001925, 2010.

Trabucho-Alexandre, J., Van Gilst, R. I., Rodríguez-López, J. P., and de Boer, P. L.: The sedimentary expression of oceanic anoxic event $1 \mathrm{~b}$ in the North Atlantic, Sedimentology, 58, 1217-1246, 2011.

Trabucho-Alexandre, J., Dirkx, R., Veld, H., Klaver, G., and de Boer, P. L.: Toarcian black shales in the Dutch Central Graben: the record of energetic, variable depositional conditions during an oceanic anoxic event, J. Sediment. Res., 82, doi:10.2110/jsr.2011.5, in press, 2012.

Twenhofel, W.: Notes on black shale in the making, Am. J. Sci., 4, 272-280, 1915.

Twenhofel, W.: Environments of origin of black shales, AAPG Bull., 23, 1178-1198, 1939.

Tyson, R. V.: Sedimentary organic matter: organic facies and palynofacies, Springer-Verlag, New York, 640 pp., 1994.

Tyson, R. V.: The "productivity versus preservation" controversy: cause, flaws, and resolution, in: The deposition of organiccarbon-rich sediments: models, mechanisms, and consequences, edited by: Harris, N. B., SEPM Spec. P., 82, 17-33, 2005.

van Andel, T. H., Thiede, J., Sclater, J. G., and Hay, W. W.: Depositional history of the South Atlantic Ocean during the last 125 Million years, J. Geol., 85, 651-698, 1977.

Walsh, J. J.: Importance of continental margins in the marine biogeochemical cycling of carbon and nitrogen, Nature, 350, 53-55, 1991.
Waples, D. W.: Reappraisal of anoxia and organic richness, with emphasis on Cretaceous of North Atlantic, AAPG Bull., 67, 963978, 1983.

Weissert, H.: The environment of deposition of black shales in the Early Cretaceous: an ongoing controversy, in: The Deep Sea Drilling Project: a decade of progress, edited by: Warme, J. E., Douglas, R. G., and Winterer, E. L., SEPM Spec. P., 32, 547560,1981

White, D. A.: Geologic risking guide for prospects and plays, AAPG Bull., 77, 2048-2061, 1993.

White, S. M.: Deep sea drilling, Geotimes, 24, 21-23, 1979.

Whitman, J., Baltuck, M., Haggerty, J., and Dean, W.: Turbidite sedimentology and history of the East Mariana basin, in: Initial Rep. Deep Sea, edited by: Moberly, R., Schlanger, S. O., Baltuck, M., Bergen, J. A., Dean, W., Floyd, P. A., Fujii, N., Haggerty, J. A., Ogg, J. G., Premoli Silva, I., Schaaf, A., Schaefer, R. G., Sliter, W. V., and Whitman, J. M., US Govt Printing Office, Washington, 89, 365-387, 1985.

Wignall, P. B.: Model for transgressive black shales?, Geology, 19, 167-170, 1991.

Wignall, P. B.: Black shales, Oxford University Press, Oxford, 127 pp., 1994.

Wignall, P. B. and Newton, R.: Black shales on the basin margin: a model based on examples from the Upper Jurassic of the Boulonnais, northern France, Sediment. Geol., 144, 335-356, 2001.

Wilde, P., Quinby-Hunt, M. S., and Erdtmann, B.-D.: Prediction of potentially metalliferous organic-rich shale locales using paleooceanographic and paleogeographic techniques, in: Mineral deposits: research and exploration, where do they meet?, edited by: Papunen, H., Balkema, Rotterdam, 125-128, 1997.

Wilson, J. T.: Did the Atlantic close and then re-open?, Nature, 211, 676-681, 1966.

Wilson, J. T.: Static or Mobile Earth: The Current Scientific Revolution, P. Am. Philos. Soc., 112, 309-320, 1968.

Wyrtki, K.: The oxygen minima in relation to ocean circulation, Deep-Sea Res., 9, 11-23, 1962.

Ziegler, P. A.: Evolution of the Arctic-North Atlantic and the Western Tethys, AAPG Memoir, 43, 198 pp., 1988.

Zimmerman, H. B., Boersma, A., and McCoy, F. W.: Carbonaceous sediments and palaeoenvironment of the Cretaceous South Atlantic Ocean, in: Marine petroleum source rocks, edited by: Brooks, A. and Fleet, A. J., Geol. Soc. Spec. Publ., 26, 271-286, 1987. 